\title{
Variations in Element Levels Accumulated in Different Parts of Boletus edulis Collected from Central Yunnan Province, China
}

\author{
Xue-Mei Wang, ${ }^{1}$ Ji Zhang, ${ }^{2}$ Tao Li, ${ }^{3}$ Jie-Qing Li, ${ }^{1}$ Yuan-Zhong Wang, ${ }^{2}$ and Hong-Gao Liu ${ }^{1}$ \\ ${ }^{1}$ College of Agronomy and Biotechnology, Yunnan Agricultural University, Kunming 650201, China \\ ${ }^{2}$ Institute of Medicinal Plants, Yunnan Academy of Agricultural Sciences, Kunming 650200, China \\ ${ }^{3}$ College of Resources and Environment, Yuxi Normal University, Yuxi 653100, China
}

Correspondence should be addressed to Yuan-Zhong Wang; boletus@126.com and Hong-Gao Liu; honggaoliu@126.com

Received 9 December 2014; Revised 17 January 2015; Accepted 24 January 2015

Academic Editor: Yuangen Yang

Copyright (C) 2015 Xue-Mei Wang et al. This is an open access article distributed under the Creative Commons Attribution License, which permits unrestricted use, distribution, and reproduction in any medium, provided the original work is properly cited.

ICP-AES and microwave assisted digestion were applied to determine $\mathrm{P}, \mathrm{Mg}, \mathrm{Ca}, \mathrm{Zn}, \mathrm{Na}, \mathrm{Cu}, \mathrm{Ba}, \mathrm{Ni}, \mathrm{V}, \mathrm{Cd}, \mathrm{Sr}, \mathrm{Co}$, and $\mathrm{Li}$ in the caps and stipes of Boletus edulis collected from six spatially distant sites in Yunnan province, China. Fruiting bodies of King Bolete are abundant in $\mathrm{P}, \mathrm{Mg}, \mathrm{Ca}, \mathrm{Zn}, \mathrm{Cu}$, and $\mathrm{Na}$, followed by $\mathrm{Ba}, \mathrm{Cd}, \mathrm{Ni}, \mathrm{V}, \mathrm{Li}, \mathrm{Sr}$, and Co. Contents of $\mathrm{P}, \mathrm{Mg}, \mathrm{Zn}$, and Cu are more abundant in caps than in stipes of King Bolete. However, elements such as $\mathrm{Na}, \mathrm{Ba}, \mathrm{Cd}, \mathrm{Ni}, \mathrm{V}, \mathrm{Li}, \mathrm{Sr}$, and Co prefer to accumulate in stipes of mushrooms from Yaoan, Chuxiong. The results of this study indicate that spatial variations of elements between caps and stipes are mainly related to different bedrock soil geochemistry and enrichment capability for various elements.

\section{Introduction}

Edible wild-grown mushrooms are traditionally consumed as delicacy in lots of countries and many are also used in traditional Chinese medicine [1-4]. This would be due to the abundant sources of protein, carbohydrates, dietary fibre and certain vitamins, and minerals as well as bioactive components [5-7]. Reports suggested that edible wild-grown mushrooms have many pharmacological effects such as antioxidant, antitumor, and hypoglycaemic effect and boosting the immune system $[8,9]$. In Yunnan province, the main wild edible and medicinal fungi are Boletus, Tricholoma, Termitomyces, Aphyllophorales, and Tuber [10].

King Bolete (Boletus edulis Bull. Fr.) is famous for its nutrition, flavor, taste, appearances, and medicinal value worldwide [11]. In China, they are mainly distributed in Yunnan, Sichuan, Fujian, Shanxi, and Guizhou province and usually grow up under the pine forest and broad-leaved forest [12]. Some alkaloid substances such as adenine, choline, and putrescine are produced by King Bolete, which are one of the ingredients of traditional Chinese medicine-Shujin Pill [11]. Besides, studies have indicated that inhibition rate of King Bolete extract for Sarcoma-180 is 100\% and 90\% for ehrlich ascites carcinoma $[13,14]$. These functional characteristics are, as suggested by Qi et al., mainly due to the type and content of trace element but other active compounds seem also to take part [15].

Edible wild-grown mushrooms have a very effective mechanism to accumulate extremely high concentrations of macro- and microelements from soil [16-19]. Recognized factors influencing the bioaccumulation of trace elements in fungi are bedrock geochemistry, fungal lifestyle, environmental pollution, specific species, and element [20-24]. Fruiting bodies of King Bolete are naturally abundant in certain essential elements including $\mathrm{P}, \mathrm{K}, \mathrm{Ca}, \mathrm{Mg}, \mathrm{Zn}, \mathrm{Fe}, \mathrm{Cu}$, and $\mathrm{Se}$, but also in $\mathrm{Hg}, \mathrm{Cd}, \mathrm{Pb}, \mathrm{Ag}$, and $\mathrm{Ni}$ which are hazardous to human [25-29].

Central Yunnan province is one of the most wild edible mushrooms resource-rich and largest production regions in China. The main species are Boletus, Leccinum, Xerocomus, Tricholoma matsutake, Termitomyces, and Thelephora ganbajun [10]. Data published on element concentration of King Bolete did indicate the considerable variation between the sites, years, and reports $[30,31]$. There is scarcity of data on minerals composition variation of King Bolete collected from China. In addition, due to the presence of hymenophore with 


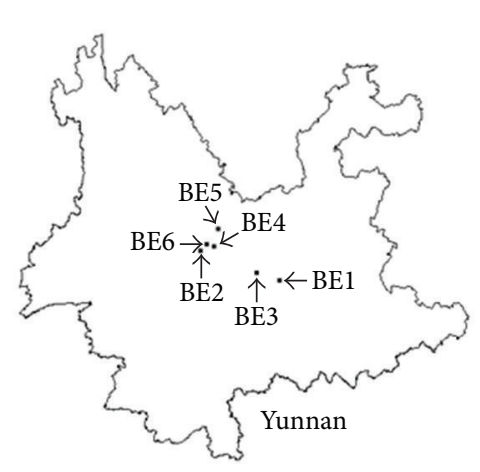

余

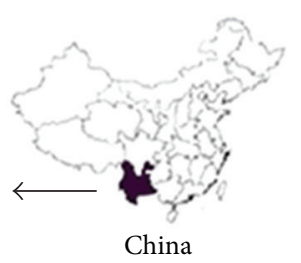

FIGURE 1: Localization of the sampling sites (dot) of Boletus edulis in central Yunnan, China.

generative spores in caps, distribution of elements is unevenly within the fruiting body of mushroom [32]. It is necessary to ascertain elements variation of King Bolete in China through knowledge of the concentrations of many essential and toxic elements. The objective was to examine and evaluate the distribution disparity in elements concentration (P, $\mathrm{Mg}, \mathrm{Ca}$, $\mathrm{Zn}, \mathrm{Na}, \mathrm{Cu}, \mathrm{Ba}, \mathrm{Ni}, \mathrm{V}, \mathrm{Cd}, \mathrm{Sr}, \mathrm{Co}$, and $\mathrm{Li}$ ) of caps and stipes of King Bolete collected from central Yunnan province, China.

\section{Materials and Methods}

2.1. Mushrooms Sampling. King Bolete (Boletus edulis Bull.: Fr.) samples were collected during summer and autumn in 2011 from six spatially distant sites in central Yunnan province, China (Figure 1). The specific site and number of specimens used in this study are given in Table 1. Fresh fruiting bodies were cleaned up with a plastic knife from visible plant or substrate debris and next separated to two parts (cap and stipe). Each sample was washed with deionized water and dried in an electrically heated oven at $65^{\circ} \mathrm{C}$ to constant weight. Dried samples were pulverized with a muller and stored in sealed polyethylene bag in dry condition for analysis.

2.2. Reagents and Apparatus. Deionized water and nitric acid solution were used to prepare all aqueous solutions and clean or soak the glassware. Nitric acid solution $\left(\mathrm{HNO}_{3} 65 \%\right)$ and hydrogen peroxide $\left(\mathrm{H}_{2} \mathrm{O}_{2} 30 \%\right)$ were used for digestion of samples in automatic microwave digestion system. The contents of the minerals in King Bolete were determined using inductively coupled plasma atomic emission spectrophotometer (ICP-9000, Shimadzu, Japan).

2.3. Analysis. $0.5 \mathrm{~g}$ of dried and powdered sample was mixed with $4 \mathrm{~mL} \mathrm{HNO}_{3}(65 \%), 2 \mathrm{~mL} \mathrm{H} \mathrm{O}_{2}(30 \%)$, and $3 \mathrm{~mL}$ deionized water in polytetrafluoroethylene (PTFE) pressure vessels and digested in microwave digestion system. Ultimate digest was transferred to $25 \mathrm{~mL}$ colorimetric cylinder using deionized water for constant volume and subjected to instrumental analysis. Concentration of all elements in caps and stipes was
TABLE 1: Locations and numbers of Boletus edulis samples collected from central Yunnan in 2011.

\begin{tabular}{lcc}
\hline Code & Location & Number of samples \\
\hline BE1 & Baofeng, Jinning, and Kunming & 11 \\
BE2 & Yulu, Nanhua, and Chuxiong & 7 \\
BE3 & Pubei, Yimen, and Yuxi & 12 \\
BE4 & Longchuan, Nanhua, and Chuxiong & 10 \\
BE5 & Qianchang, Yaoan, and Chuxiong & 8 \\
BT6 & Shaqiao, Nanhua, and Chuxiong & 8 \\
\hline
\end{tabular}

determined using inductively coupled plasma atomic emission spectrophotometer and for blank solutions and certified reference material (GBW07605) as well. Discrepancies between certified values and concentrations quantified were all below $10 \%$.

\section{Results and Discussion}

Data on the parameters determined for caps and stipes of King Bolete are presented in Table 2. The element concentrations vary significantly not only among the collection sites but also within morphological parts of a particular fruiting body. Samples of King Bolete collected from different sites show rich content in $\mathrm{P}, \mathrm{Mg}, \mathrm{Ca}, \mathrm{Zn}, \mathrm{Cu}$, and $\mathrm{Na}$ which accumulate both in cap and in stipe, followed by $\mathrm{Ba}, \mathrm{Cd}, \mathrm{Ni}, \mathrm{V}, \mathrm{Li}, \mathrm{Co}$, and Sr. Meanwhile, prominent differences in the concentrations of these elements are also found in the caps and in the stipes of King Bolete.

$\mathrm{Qc} / \mathrm{s}$ value is a quotient between the minerals concentrations in caps and stipes, which is used to express the elements distribution within the fruiting body of the mushrooms. Significant differences have been suggested in loads of accumulated elements between caps and stipes, and some were caused by the site or year of mushroom collection [30, $31,33]$. In this study, multivariate $\mathrm{Qc} / \mathrm{s}$ values are obtained between the elements and collection sites (Table 2). Minerals such as $\mathrm{P}, \mathrm{Mg}, \mathrm{Zn}$, and $\mathrm{Cu}$ prefer to accumulate in the cap of King Bolete collected of all sites in this study. Except for the prevailing elements $\mathrm{P}, \mathrm{Mg}, \mathrm{Zn}, \mathrm{Ca}$, and $\mathrm{Cu}, \mathrm{Qc} / \mathrm{s}$ values for other elements in King Bolete collected from BE5 are $<1$. Consequently, these different distributions of elements between caps and stipes are mainly related to different bedrock soil geochemistry and ability to accumulate various elements.

3.1. Essential Elements: $\mathrm{P}, \mathrm{Mg}, \mathrm{Ca}, \mathrm{Zn}, \mathrm{Na}, \mathrm{Cu}$, $\mathrm{Ni}$, and $\mathrm{Co}$. $\mathrm{P}$ is the essential element that nearly participates in all physiological chemical reactions such as forming the bones, teeth, and nucleic acid, maintaining balance of ATP metabolism, and regulating acid-base balance. Rich concentrations are found in King Bolete and with the range of $4356-9013 \mathrm{mg} \mathrm{kg}^{-1}$ and $2150-3891 \mathrm{mg} \mathrm{kg}^{-1} \mathrm{dm}$ for cap and stipe, respectively. So contents in caps are higher than in stipes, and Qc/s values vary between 1.62 and 2.57 (Table 2). King Bolete collected from mountain area of Liaoning province in China with $4995 \mathrm{mg} \mathrm{kg}^{-1} \mathrm{dm}$ agreed with this study [11]. P value 
TABLE 2: Elements content of Boletus edulis collected from central part of Yunnan province in 2011 (mg/kg dm, mean, SD, range).

\begin{tabular}{|c|c|c|c|c|c|c|}
\hline Elements & BE1 & BE2 & BE3 & $\mathrm{BE} 4$ & BE5 & BE6 \\
\hline \multicolumn{7}{|l|}{$\mathrm{P}$} \\
\hline \multirow{2}{*}{ Cap } & $5523 \pm 1070$ & $9013 \pm 2328$ & $5528 \pm 705$ & $6021 \pm 1044$ & $4356 \pm 1146$ & $5420 \pm 1410$ \\
\hline & 1429-13588 & $11620-13010$ & $4451-6406$ & $3970-7381$ & $1285-5655$ & $2339-7256$ \\
\hline \multirow{2}{*}{ Stipe } & $3022 \pm 535$ & $3891 \pm 965$ & $2150 \pm 406$ & $3616 \pm 1577$ & $2668 \pm 668$ & $3348 \pm 1229$ \\
\hline & $1614-6086$ & $2635-5008$ & 1595-2794 & $1679-7179$ & $1285-3435$ & $3966-5730$ \\
\hline $\mathrm{Qc} / \mathrm{s}$ & 1.83 & 2.32 & 2.57 & 1.67 & 1.63 & 1.62 \\
\hline \multicolumn{7}{|l|}{$\mathrm{Mg}$} \\
\hline \multirow{2}{*}{ Cap } & $1221 \pm 64$ & $1447 \pm 137$ & $935 \pm 184$ & $1138 \pm 185$ & $1028 \pm 163$ & $918 \pm 173$ \\
\hline & $332-3071$ & $2116-2334$ & 737-1404 & $782-1416$ & $365-1397$ & 580-1136 \\
\hline \multirow{2}{*}{ Stipe } & $705 \pm 42$ & $710 \pm 143$ & $442 \pm 59$ & $939 \pm 261$ & $620 \pm 48$ & $636 \pm 156$ \\
\hline & $406-1771$ & $462-889$ & $339-523$ & $607-1393$ & $653-645$ & $761-942$ \\
\hline Qc/s & 1.73 & 2.04 & 2.12 & 1.21 & 1.66 & 1.44 \\
\hline \multicolumn{7}{|l|}{$\mathrm{Ca}$} \\
\hline \multirow{2}{*}{ Cap } & $212 \pm 15$ & $249 \pm 64$ & $656 \pm 126$ & $635 \pm 114$ & $339 \pm 104$ & $367 \pm 149$ \\
\hline & $34-260$ & $303-476$ & $199-2435$ & $353-1118$ & $189-487$ & 204-924 \\
\hline \multirow{2}{*}{ Stipe } & $209 \pm 11$ & $236 \pm 72$ & $239 \pm 68$ & $952 \pm 202$ & $144 \pm 59$ & $373 \pm 121$ \\
\hline & $26-279$ & $115-338$ & $125-349$ & $151-1632$ & $67-259$ & $170-750$ \\
\hline $\mathrm{Qc} / \mathrm{s}$ & 1.01 & 1.06 & 2.74 & 0.67 & 2.35 & 0.98 \\
\hline \multicolumn{7}{|l|}{$\mathrm{Zn}$} \\
\hline \multirow{2}{*}{ Cap } & $128 \pm 69$ & $534 \pm 122$ & $204 \pm 72$ & $113 \pm 26$ & $54 \pm 16.6$ & $86 \pm 21$ \\
\hline & 29-299 & $426-1370$ & $102-652$ & $79-167$ & $16-71$ & $38-103$ \\
\hline \multirow{2}{*}{ Stipe } & $65 \pm 13$ & $332 \pm 82$ & $60 \pm 24$ & $66 \pm 12$ & $35 \pm 9.3$ & $47 \pm 23$ \\
\hline & $38-134$ & $61-512$ & $39-120$ & $27-176$ & $16-45$ & $26-84$ \\
\hline $\mathrm{Qc} / \mathrm{s}$ & 1.97 & 1.61 & 3.4 & 1.71 & 1.54 & 1.83 \\
\hline \multicolumn{7}{|l|}{$\mathrm{Na}$} \\
\hline \multirow{2}{*}{ Cap } & $19.3 \pm 5.8$ & $35.2 \pm 16.7$ & $15.3 \pm 9.9$ & $100 \pm 21$ & $63 \pm 6.7$ & $2.9 \pm 0.4$ \\
\hline & $5.8-57.2$ & $5.2-134$ & $3.8-89$ & $38-156$ & $55-74$ & $1.3-5.8$ \\
\hline \multirow{2}{*}{ Stipe } & $19.6 \pm 6.2$ & $27.5 \pm 5$ & $23.5 \pm 8.1$ & $129 \pm 34$ & $95 \pm 17$ & $148 \pm 47$ \\
\hline & $3.9-73.0$ & $2.1-41.1$ & $5.8-102$ & 69-202 & $62-143$ & $16-242$ \\
\hline $\mathrm{Qc} / \mathrm{s}$ & 0.98 & 1.28 & 0.65 & 0.77 & 0.66 & 0.02 \\
\hline \multicolumn{7}{|l|}{$\mathrm{Cu}$} \\
\hline \multirow{2}{*}{ Cap } & $33.6 \pm 1.8$ & $884 \pm 63$ & $40.3 \pm 17$ & $53.4 \pm 44$ & $17 \pm 5.7$ & $26.8 \pm 8$ \\
\hline & $11.5-81.3$ & 57-3025 & $22-79$ & 19-202 & $5.4-23.5$ & $17.3-41$ \\
\hline \multirow{2}{*}{ Stipe } & $19.2 \pm 2.3$ & $703 \pm 49$ & $20.4 \pm 11$ & $32 \pm 21$ & $8.6 \pm 2.7$ & $13.9 \pm 3.8$ \\
\hline & $10.6-52.3$ & $24-1496$ & $9-54$ & $14-87$ & $5.4-13$ & $9-20$ \\
\hline $\mathrm{Qc} / \mathrm{s}$ & 1.75 & 1.26 & 1.98 & 1.67 & 1.98 & 1.93 \\
\hline $\mathrm{Ni}$ & & & & & & \\
\hline Can & $2.7 \pm 0.8$ & $5.2 \pm 1.1$ & $2.1 \pm 0.35$ & $5.2 \pm 1.8$ & $2.4 \pm 0.7$ & $63.7 \pm 14$ \\
\hline Cap & $1.27-4.33$ & $3-9.9$ & $1.5-2.6$ & $2.1-7.9$ & $1.2-3.2$ & $49-83$ \\
\hline Stine & $1.7 \pm 0.6$ & $2.3 \pm 0.42$ & $1.1 \pm 0.22$ & $5.1 \pm 3.1$ & $16.7 \pm 8$ & $42.9 \pm 16$ \\
\hline Stipe & $1.05-2.66$ & $1.86-2.96$ & $0.77-1.54$ & $2.3-15.2$ & $1.2-25.7$ & $25-62$ \\
\hline $\mathrm{Qc} / \mathrm{s}$ & 1.59 & 2.26 & 1.91 & 1.02 & 0.14 & 1.48 \\
\hline Co & & & & & & \\
\hline Can & $1.0 \pm 0.34$ & $0.8 \pm 0.36$ & $1.1 \pm 0.39$ & $0.9 \pm 0.21$ & $0.4 \pm 0.1$ & $8.4 \pm 2.7$ \\
\hline Cap & $0.53-1.61$ & $0.29-1.64$ & $0.55-1.79$ & $0.54-1.36$ & $0.19-0.49$ & $4-13.6$ \\
\hline Stine & $0.9 \pm 0.25$ & $0.5 \pm 0.15$ & $1.0 \pm 0.61$ & $0.8 \pm 0.18$ & $4.6 \pm 1.7$ & $6.3 \pm 2.4$ \\
\hline Stipe & $0.34-2.13$ & $0.27-0.67$ & $0.38-2.04$ & $0.31-2.56$ & $0.39-5.9$ & $2.5-8.7$ \\
\hline $\mathrm{Qc} / \mathrm{s}$ & 1.11 & 1.6 & 1.1 & 1.13 & 0.09 & 1.33 \\
\hline $\mathrm{Ba}$ & & & & & & \\
\hline Can & $8.1 \pm 1.1$ & $9.7 \pm 3.4$ & $6.6 \pm 1.9$ & $9.9 \pm 4$ & $4.8 \pm 1.5$ & $66.7 \pm 32$ \\
\hline cap & $2.59-12.0$ & $3.96-20.3$ & $3.44-9.13$ & $4.5-18.2$ & $2.7-6.9$ & $26-136$ \\
\hline Stine & $5.3 \pm 0.58$ & $4.4 \pm 1.37$ & $2.7 \pm 0.7$ & $9.6 \pm 3.4$ & $65.5 \pm 20$ & $41.1 \pm 13$ \\
\hline Stipe & $3.27-7.81$ & $2.62-6.85$ & $1.78-3.84$ & $5.4-25.1$ & $3.4-73$ & $25-63$ \\
\hline $\mathrm{Qc} / \mathrm{s}$ & 1.53 & 2.2 & 2.44 & 1.03 & 0.07 & 1.62 \\
\hline
\end{tabular}


TABLE 2: Continued.

\begin{tabular}{|c|c|c|c|c|c|c|}
\hline Elements & BE1 & BE2 & BE3 & BE4 & BE5 & BE6 \\
\hline \multicolumn{7}{|l|}{$\bar{V}$} \\
\hline \multirow{2}{*}{ Cap } & $1.7 \pm 0.56$ & $3.9 \pm 0.86$ & $1.2 \pm 0.34$ & $3.7 \pm 0.8$ & $1.6 \pm 0.7$ & $27.3 \pm 10.5$ \\
\hline & $0.6-2.85$ & $1.24-8.75$ & $0.65-1.64$ & $0.98-7.29$ & $0.7-2.82$ & $12.5-46.6$ \\
\hline \multirow{2}{*}{ Stipe } & $1.1 \pm 0.34$ & $1.4 \pm 0.41$ & $0.5 \pm 0.02$ & $3.4 \pm 1.1$ & $15.3 \pm 4.8$ & $15.8 \pm 7.5$ \\
\hline & $0.45-1.93$ & $1.02-2.11$ & $0.33-0.92$ & $1.5-11.1$ & $0.9-23.9$ & $8-30$ \\
\hline $\mathrm{Qc} / \mathrm{s}$ & 1.55 & 2.79 & 2.4 & 1.09 & 0.1 & 1.73 \\
\hline \multicolumn{7}{|l|}{$\mathrm{Cd}$} \\
\hline \multirow{2}{*}{ Cap } & $2.1 \pm 0.3$ & $5.3 \pm 1.9$ & $1.2 \pm 0.35$ & $1.4 \pm 0.67$ & $1.6 \pm 0.6$ & $24.8 \pm 5.6$ \\
\hline & $0.48-5.37$ & $1.2-13$ & $0.74-2.05$ & $0.76-2.99$ & $0.41-2.6$ & $11.8-36.5$ \\
\hline \multirow{2}{*}{ Stipe } & $0.9 \pm 0.25$ & $1.5 \pm 0.03$ & $0.5 \pm 0.1$ & $0.9 \pm 0.72$ & $5.1 \pm 1.9$ & $10.1 \pm 2.3$ \\
\hline & $0.35-1.95$ & $0.96-2.23$ & $0.31-0.82$ & $0.19-4.45$ & $0.5-9.1$ & $4-16.5$ \\
\hline $\mathrm{Qc} / \mathrm{s}$ & 2.33 & 3.53 & 2.4 & 1.56 & 0.31 & 2.46 \\
\hline \multicolumn{7}{|l|}{$\mathrm{Sr}$} \\
\hline \multirow{2}{*}{ Cap } & $4.4 \pm 0.32$ & $1.5 \pm 0.1$ & $1.5 \pm 0.4$ & $2.1 \pm 0.57$ & $0.9 \pm 0.3$ & $11.5 \pm 5.9$ \\
\hline & $0.5-23.5$ & $0.45-3.34$ & $0.92-2.5$ & $1.13-2.89$ & $0.56-1.54$ & $6.7-24.8$ \\
\hline \multirow{2}{*}{ Stipe } & $1.4 \pm 0.5$ & $0.9 \pm 0.2$ & $1.0 \pm 0.37$ & $1.9 \pm 1$ & $9.7 \pm 3.1$ & $9.9 \pm 2.6$ \\
\hline & $0.78-2.14$ & 0.59-1.09 & $0.64-1.82$ & $0.53-4.26$ & $0.59-15.4$ & $6.8-12.9$ \\
\hline $\mathrm{Qc} / \mathrm{s}$ & 3.14 & 1.67 & 1.5 & 1.11 & 0.09 & 1.16 \\
\hline \multicolumn{7}{|l|}{$\mathrm{Li}$} \\
\hline \multirow{2}{*}{ Cap } & $0.6 \pm 0.03$ & $1.6 \pm 0.2$ & $0.3 \pm 0.05$ & $1.6 \pm 0.85$ & $1.2 \pm 0.45$ & $5.9 \pm 1.3$ \\
\hline & $0.37-1.02$ & $0.57-3.68$ & $0.18-0.36$ & $0.29-3.27$ & $0.7-2.1$ & $1.2-8.7$ \\
\hline \multirow{2}{*}{ Stipe } & $0.4 \pm 0.02$ & $0.6 \pm 0.17$ & $0.2 \pm 0.08$ & $1.4 \pm 1.1$ & $3.1 \pm 1.13$ & $4.3 \pm 1.26$ \\
\hline & $0.06-0.91$ & $0.42-0.88$ & $0.07-0.33$ & $0.57-3.96$ & $0.87-4.1$ & $0.3-3.89$ \\
\hline $\mathrm{Qc} / \mathrm{s}$ & 1.5 & 2.67 & 1.5 & 1.14 & 0.39 & 1.37 \\
\hline
\end{tabular}

$\mathrm{Qc} / \mathrm{s}$ is the ratio of the element concentration in cap to stipe.

in fruiting body (cap and stipe) and Qc/s of King Bolete is insufficient.

Caps of King Bolete contain $\mathrm{Mg}$ at $918-1447 \mathrm{mg} \mathrm{kg}^{-1} \mathrm{dm}$, which are higher than for stipes (442-939 $\mathrm{mg} \mathrm{kg}^{-1} \mathrm{dm}$ ). Lower values of $590-960 \mathrm{mg} \mathrm{kg}^{-1} \mathrm{dm}$ were obtained for caps of King Bolete collected from Poland [31, 33, 34]. However, in the study by Liu et al. [23], elevated contents of Mg (1100$1500 \mathrm{mg} \mathrm{kg}^{-1} \mathrm{dm}$ ) were got in wild-grown mushroom such as Catathelasma ventricosum, Laccaria amethystina, and Stropharia rugoso-annulata.

$\mathrm{Ca}$ is the activator of more than 200 kinds of enzymes in the human body, which can make each organ function well. $\mathrm{Na}$ concentration values distribution in King Bolete varies depending on the sites (Table 2). Qc/s values for Ca vary between 0.67 and 2.74, and contents of stipes for BE4 (0.67) exceed that of caps, and opposite feature could be observed for BE3 (2.74) and BE5 (2.35), while they are similar for BE1 (1.01), BE2 (1.06), and BE6 (0.98).

Zinc contents were reported at between 28 and $140 \mathrm{mg} \mathrm{kg}^{-1} \mathrm{dm}$ for edible wild-grown mushrooms collected from China [7]. Meanwhile, higher concentration was also reported showing its physiological importance to mushroom. The examples are as follows: $190 \mathrm{mg} \mathrm{kg}^{-1} \mathrm{dm}$ (cap) [34], $240 \mathrm{mg} \mathrm{kg}^{-1} \mathrm{dm}$ (cap) [35], and $580 \mathrm{mg} \mathrm{kg}^{-1} \mathrm{dm}$ (whole fruiting body) [30]. As shown in Table 2, stipes of King Bolete are half or even less than caps in essential $\mathrm{Zn}$, and value of Qc/s for Zn in this study is 1.54-3.4, which extremely agrees with literature data previously reported [16]. Nevertheless, a higher value $(\mathrm{Q} / \mathrm{s}=4.6)$ was reported in fruiting body of King Bolete collected from Xichang in Sichuan province, China [36].

$\mathrm{Na}$ content for caps is between 2.9 and $100 \mathrm{mg} \mathrm{kg}^{-1} \mathrm{dm}$ and for stipes between 19.6 and $148 \mathrm{mg} \mathrm{kg}^{-1} \mathrm{dm}$. Higher values were determined in cultivated and some preserved mushrooms and content was 860, 1000, and 16000$25000 \mathrm{mg} \mathrm{kg}^{-1} \mathrm{dm}$ for Agaricus bisporus (whole), Lentinula edodes, and Agaricus bisporus (preserved), respectively [3739]. $\mathrm{Na}$ is present higher in concentrations in stipes than in caps, except for samples collected from BE2 (Yulu, Nanhua) with the value of 1.28 (Table 2). Published data in stipes of King Bolete are about twice more abundant in $\mathrm{Na}$ than the caps [16]. Report also suggested the similar Qc/s value (0.45) for sodium in parasol mushroom Macrolepiota procera [40].

$\mathrm{Cu}$ is an essential element, and a large variation of values is noted; they ranged, respectively, between 17-884 and 8.6$703 \mathrm{mg} \mathrm{kg}^{-1} \mathrm{dm}$ for caps and stipes (Table 2). Cu in this study is more abundant in caps than stipes of King Bolete, and Qc/s value varies between 1.26 and 1.98. Higher Qc/s value of 2.8 was obtained for King Bolete collected from Pbocka Dale in Poland [34]. In addition, $\mathrm{Cu}$ contents in caps of Leccinum mushrooms from Poland were half or even less than in stipes [41].

Published data on $\mathrm{Ni}$ and Co in caps and stipes of King Bolete is few and relatively insufficient. Ni content of King Bolete at six sites varied between 2.1 and $63.7 \mathrm{mg} \mathrm{kg}^{-1} \mathrm{dm}$ in caps and between 1.1 and $42.9 \mathrm{mg} \mathrm{kg}^{-1} \mathrm{dm}$ in stipes. The mean Co concentrations were $0.4-8.4$ and $0.5-6.4 \mathrm{mg} \mathrm{kg}^{-1}$ for caps and stipes, respectively. Published data on Co contents were 
usually below or around $0.5 \mathrm{mg} / \mathrm{kg} \mathrm{DM}$, which were lower than the results in this study [42]. Contents in caps are somewhat higher than those in stipes except sample collected from BE5; that is, Qc/s value is 1.02-2.26 and 1.1-1.6 for $\mathrm{Ni}$ and Co, respectively.

3.2. $\mathrm{Ba}, \mathrm{V}, \mathrm{Cd}, \mathrm{Sr}$, and $\mathrm{Li}$. As shown in Table 2, Ba, V, $\mathrm{Cd}, \mathrm{Sr}$, and $\mathrm{Li}$ contents in samples from BE6 are obviously higher than those from other regions, which is most probably depending on the geological bedrock in this site. Arithmetic mean of Qc/s for these elements is 1.03-3.53; nevertheless, for certain site (BE5) the Qc/s value is $<1$.

$\mathrm{Ba}$ content is in the range of 4.8-66.7 and 2.7-65.5 for caps and stipes, respectively, and these values are particularly higher than the reference data previously reported, which were $0.2-1.5 \mathrm{mg} \mathrm{kg}^{-1} \mathrm{dm}$ for caps and $0.36-1.4 \mathrm{mg} \mathrm{kg}^{-1} \mathrm{dm}$ for stipes [30, 31, 33, 34].

Reports on $\mathrm{V}$ contents on King Bolete were very few, and literature data were $0.02-0.09 \mathrm{mg} \mathrm{kg}^{-1} \mathrm{dm}$ in caps, $0.03 \mathrm{mg} \mathrm{kg}^{-1} \mathrm{dm}$ in stipes, and $1.27 \mathrm{mg} \mathrm{kg}^{-1} \mathrm{dm}$ in whole fruiting body [27, 31]. King Bolete in this study contains $\mathrm{V}$ at elevated concentrations; for caps it is $1.2-27.3 \mathrm{mg} \mathrm{kg}^{-1} \mathrm{dm}$ and for stipes at 0.5 to $15.8 \mathrm{mg} \mathrm{kg}^{-1} \mathrm{dm}, \mathrm{Qc} / \mathrm{s}$ value is $0.1-2.79$.

$\mathrm{Cd}$ is toxic metallic element is found in edible mushrooms and can leach out of fruiting bodies during boiling. Tolerance limit is $2 \mu \mathrm{g} / \mathrm{g} \mathrm{dm}$ for cultivated mushroom, and no such tolerances exist for edible wild-grown fungi [43]. Apart from the highest value $\left(24.8 \mathrm{mg} \mathrm{kg}^{-1} \mathrm{dm}\right)$ of cap from EB6, other values are relatively low, which is consistent with the results of earlier studies [16].

King Bolete contains $\mathrm{Sr}$ at $0.9-11.5 \mathrm{mg} \mathrm{kg}^{-1} \mathrm{dm}$ in caps and at $0.9-9.9 \mathrm{mg} \mathrm{kg}^{-1} \mathrm{dm}$ in stipes, which is higher value than for samples from Poland. Most of the sites surveyed caps, when compared to stipes containing higher content of $\mathrm{Sr}$, and opposite feature was found in earlier reports [30, 31, 33, 34].

The lithium salt, $\mathrm{Li}_{2} \mathrm{CO}_{3}$, is considered as a therapeutic for neurodisorders. Li is a trace element in fungi, and content is relatively low [16]. Li content of King Bolete from Italy was between 0.04 and $0.9 \mathrm{mg} \mathrm{kg}^{-1} \mathrm{dm}$ [44]. Higher results are determined in present study: mean value of $\mathrm{Li}$ is from 0.3 to $5.9 \mathrm{mg} \mathrm{kg}^{-1} \mathrm{dm}$ in caps and from 0.2 to $4.3 \mathrm{mg} \mathrm{kg}^{-1} \mathrm{dm}$ in stipes.

\section{Conclusion}

King Bolete collected from central Yunnan province contained high content of elements such as $\mathrm{P}, \mathrm{Mg}, \mathrm{Ca}, \mathrm{Zn}, \mathrm{Na}$, and $\mathrm{Cu}$, next for $\mathrm{Ba}, \mathrm{Ni}, \mathrm{V}, \mathrm{Cd}$, and $\mathrm{Sr}$, and the least for $\mathrm{Co}$ and Li. Distribution of elements in different parts of King Bolete was unevenly, mainly depending on the hymenophore in the caps. In addition, spatial variations of Qc/s value were noted for King Bolete from different sites, which seem to be due to variations in local soil substrate geochemistry. Our results indicated that there is a close relationship between element concentrations and hymenophore in cap and bedrock soil geochemistry.

\section{Conflict of Interests}

The authors declare that there is no conflict of interests regarding the publication of this paper.

\section{Acknowledgments}

This study has been supported by the National Natural Science Foundation of China $(31460538,31260496$, and 31160409), the Special Project on the Countryside Comprehensive Reform (2014NG007-18), and the Science Foundation of the Yunnan Province Department of Education (2013Z074).

\section{References}

[1] G. Liu, H. Wang, B. Zhou, X. Guo, and X. Hu, "Compositional analysis and nutritional studies of Tricholoma matsutake collected from Southwest China," Journal of Medicinal Plants Research, vol. 4, no. 12, pp. 1222-1227, 2010.

[2] S. Beluhan and A. Ranogajec, "Chemical composition and nonvolatile components of Croatian wild edible mushrooms," Food Chemistry, vol. 124, no. 3, pp. 1076-1082, 2011.

[3] E. Pereira, L. Barros, A. Martins, and I. C. F. R. Ferreira, "Towards chemical and nutritional inventory of Portuguese wild edible mushrooms in different habitats," Food Chemistry, vol. 130, no. 2, pp. 394-403, 2012.

[4] P. Kalač, "A review of chemical composition and nutritional value of wild-growing and cultivated mushrooms," Journal of the Science of Food and Agriculture, vol. 93, no. 2, pp. 209-218, 2013.

[5] P. C. K. Cheung, "The nutritional and health benefits of mushrooms," Nutrition Bulletin, vol. 35, no. 4, pp. 292-299, 2010.

[6] J. Szubstarska, G. Jarzyńska, and J. Falandysz, "Trace elements in Variegated Bolete (Suillus variegatus) fungi," Chemical Papers, vol. 66, no. 11, pp. 1026-1031, 2012.

[7] X. M. Wang, J. Zhang, L. H. Wu et al., "A mini-review of chemical composition and nutritional value of edible wildgrown mushroom from China," Food Chemistry, vol. 151, pp. 279-285, 2014.

[8] E. Sesli, M. Tuzen, and M. Soylak, "Evaluation of trace metal contents of some wild edible mushrooms from Black sea region, Turkey," Journal of Hazardous Materials, vol. 160, no. 2-3, pp. 462-467, 2008.

[9] M. Aloupi, G. Koutrotsios, M. Koulousaris, and N. Kalogeropoulos, "Trace metal contents in wild edible mushrooms growing on serpentine and volcanic soils on the island of Lesvos, Greece," Ecotoxicology and Environmental Safety, vol. 78, pp. 184-194, 2012.

[10] L. M. Tai, C. Y. Zhao, X. Guo, M. Ma, and B. Liu, "Prospects of exploitation and utilization on several kinds of high economic value of wild edible and medicinal fungi resource in Yunnan," Edible Fungi of China, vol. 32, pp. 4-6, 2013.

[11] Y. Yu, "Determination of microelements in Boletus mushrooms by means of ICP-MS," Acta Agriculturae Boreali-Occidentalis Sinica, vol. 18, pp. 269-272, 2009.

[12] B. W. Deng, W. Q. Chen, and X. S. Li, "Comparison of the nutritive components in submerged fermentation mycelia and fructification of Boletus edulis," Food Science, vol. 25, pp. 255258, 2004. 
[13] G. H. Zhao, Z. D. Chen, Z. X. Li, and J. Q. Kan, "New progress in research on active polysaccharides," Food and Fermentation, vol. 27, pp. 45-48, 2001.

[14] W. Tang and X. C. Lu, "Study of the biological activity and the antitumor activity against Sarcoma-180 of Boletus edulis," Journal of Southwest China Normal University, vol. 24, pp. 478481, 1999.

[15] J. S. Qi, H. B. Xu, J. Y. Zhou, X. H. Lu, X. L. Yang, and J. H. Guan, "Factor analysis and cluster analysis of trace elements in some Chinese medicinal herbs," Chinese Journal of Analytical Chemistry, vol. 26, no. 11, pp. 1313-1314, 1998.

[16] J. Falandysz and J. Borovička, "Macro and trace mineral constituents and radionuclides in mushrooms: health benefits and risks," Applied Microbiology and Biotechnology, vol. 97, no. 2, pp. 477-501, 2013.

[17] A. Brzostowski, G. Jarzyńska, A. K. Kojta, D. Wydmańska, and J. Falandysz, "Variations in metal levels accumulated in Poison Pax (Paxillus involutus) mushroom collected at one site over four years," Journal of Environmental Science and Health. Part A, vol. 46, no. 6, pp. 581-588, 2011.

[18] G. Jarzyńska and J. Falandysz, "Trace elements profile of Slate Bolete (Leccinum duriusculum) mushroom and associated upper soil horizon," Journal of Geochemical Exploration, vol. 121, pp. 69-75, 2012.

[19] M. Gucia, G. Jarzyńska, E. Rafał et al., "Multivariate analysis of mineral constituents of edible Parasol Mushroom (Macrolepiota procera) and soils beneath fruiting bodies collected from Northern Poland," Environmental Science and Pollution Research, vol. 19, no. 2, pp. 416-431, 2012.

[20] J. Falandysz, I. C. Nnorom, G. Jarzyńska, D. Romińska, and K. Damps, "Mercury bio-concentration by Puffballs (Lycoperdon perlatum) and evaluation of dietary intake risks," Bulletin of Environmental Contamination and Toxicology, vol. 89, no. 4, pp. 759-763, 2012.

[21] J. Borovička and Z. Řanda, "Distribution of iron, cobalt, zinc and selenium in macrofungi," Mycological Progress, vol. 6, no. 4, pp. 249-259, 2007.

[22] M. Mleczek, M. Siwulski, K. Stuper-Szablewska, K. Sobieralski, Z. Magdziak, and P. Goliński, "Accumulation of elements by edible mushroom species II. A comparison of aluminium, barium and nutritional element contents," Journal of Environmental Science and Health Part B, vol. 48, no. 4, pp. 308-317, 2013.

[23] H. Liu, J. Zhang, T. Li, Y. Shi, and Y. Wang, "Mineral element levels in wild edible mushrooms from Yunnan, China," Biological Trace Element Research, vol. 147, no. 1-3, pp. 341-345, 2012.

[24] J. Falandysz and L. Bielawski, "Mercury and its bioconcentration factors in Brown Birch Scaber Stalk (Leccinum scabrum) from various sites in Poland," Food Chemistry, vol. 105, no. 2, pp. 635-640, 2007.

[25] J. Falandysz, "Selenium in edible mushrooms," Journal of Environmental Science and Health, Part C Environmental Carcinogenesis and Ecotoxicology Reviews, vol. 26, no. 3, pp. 256-299, 2008.

[26] M. Mleczek, M. Siwulski, K. Stuper-Szablewska, I. Rissmann, K. Sobieralski, and P. Goliński, "Accumulation of elements by edible mushroom species. Part I. Problem of trace element toxicity in mushrooms," Journal of Environmental Science and Health. Part B, vol. 48, no. 1, pp. 69-81, 2013.

[27] F. A. Ayaz, T. A. Colak, E. Sesli, M. Millson, and R. H. Glew, "Macro-and microelement contents of fruiting bodies of wildedible mushrooms growing in the East Black Sea Region of Turkey," Food and Nutrition Sciences, vol. 2, pp. 53-59, 2011.
[28] J. Falandysz and L. Bielawski, "Mercury content of wild edible mushrooms collected near the town of Augustów," Polish Journal of Environmental Studies, vol. 10, no. 1, pp. 67-71, 2001.

[29] Y. Zhang and G. Yang, "Heavy metal contents of some wild edible mushrooms from Miyi, China," Applied Mechanics and Materials, vol. 490-491, pp. 142-145, 2014.

[30] J. Falandysz, A. Frankowska, G. Jarzyńska, A. Dryżałowska, A. K. Kojta, and D. Zhang, "Survey on composition and bioconcentration potential of 12 metallic elements in king bolete (Boletus edulis) mushroom that emerged at 11 spatially distant sites," Journal of Environmental Science and Health, Part B: Pesticides, Food Contaminants, and Agricultural Wastes, vol. 46, no. 3, pp. 231-246, 2011.

[31] J. Falandysz, T. Kunito, R. Kubota et al., "Multivariate characterization of elements accumulated in King Bolete Boletus edulis mushroom at lowland and high mountain regions," Journal of Environmental Science and Health-Part A: Toxic/Hazardous Substances and Environmental Engineering, vol. 43, no. 14, pp. 1692-1699, 2008.

[32] Z. Řanda and J. Kučera, "Trace elements in higher fungi (mushrooms) determined by activation analysis," Journal of Radioanalytical and Nuclear Chemistry, vol. 259, no. 1, pp. 99-107, 2004.

[33] D. Zhang, A. Frankowska, G. Jarzyńska et al., "Metals of king bolete (Boletus edulis) bull.: fr. collected at the same site over two years," African Journal of Agricultural Research, vol. 5, no. 22, pp. 3050-3055, 2010.

[34] A. Frankowska, J. Ziołkowska, L. Bielawski, and J. Falandysz, "Profile and bioconcentration of minerals by King Bolete (Boletus edulis) from the Płocka Dale in Poland," Food Additives and Contaminants: Part B Surveillance, vol. 3, no. 1, pp. 1-6, 2010.

[35] J. Falandysz, T. Kunito, R. Kubota et al., "Selected elements in Brown Birch Scaber Stalk Leccinum scabrum," Journal of Environmental Science and Health Part A, vol. 42, no. 14, pp. 20812088, 2007.

[36] P. Ma, D. Zhang, L. B. Yang, and X. D. Zeng, "Bioaccumulation of heavy metal in wild edible Boletus fruiting body," Environmental Science and Technology, vol. 35, pp. 5-8, 2012.

[37] J. Vetter, "Chemical composition of fresh and conserved Agaricus bisporus mushroom," European Food Research and Technology, vol. 217, no. 1, pp. 10-12, 2003.

[38] P. Manzi, L. Gambelli, S. Marconi, V. Vivanti, and L. Pizzoferrato, "Nutrients in edible mushrooms: an inter-species comparative study," Food Chemistry, vol. 65, no. 4, pp. 477-482, 1999.

[39] J. Vetter, C. Hajdú, J. Györfi, and P. Maszlavér, "Mineral composition of the cultivated mushrooms Agaricus bisporus, Pleurotus ostreatus and Lentinula edodes," Acta Alimentaria, vol. 34, no. 4, pp. 441-451, 2005.

[40] E. Kułdo, G. Jarzyńska, M. Gucia, and J. Falandysz, "Mineral constituents of edible parasol mushroom Macrolepiota procera (Scop. ex Fr.) sing and soils beneath its fruiting bodies collected from a rural forest area," Chemical Papers, vol. 68, no. 4, pp. 484492, 2014.

[41] D. Zhang, Y. Zhang, E. Morawska et al., "Trace Elements in Leccinum scabrum mushrooms and topsoils from Kłodzka Dale in Sudety Mountains, Poland," Journal of Mountain Science, vol. 10, no. 4, pp. 621-627, 2013.

[42] P. Kalač, "Trace element contents in European species of wild growing edible mushrooms: a review for the period 2000-2009," Food Chemistry, vol. 122, no. 1, pp. 2-15, 2010. 
[43] European Union, "Commission regulation (EC) no 629/2008 of 2 July 2008 amending regulation (EC) no 1881/2006 setting maximum levels for certain contaminants in foodstuffs," Official Journal of the European Union, vol. L173, pp. 6-9, 2008.

[44] G. Giannaccini, L. Betti, L. Palego et al., "The trace element content of top-soil and wild edible mushroom samples collected in Tuscany, Italy," Environmental Monitoring and Assessment, vol. 184, no. 12, pp. 7579-7595, 2012. 

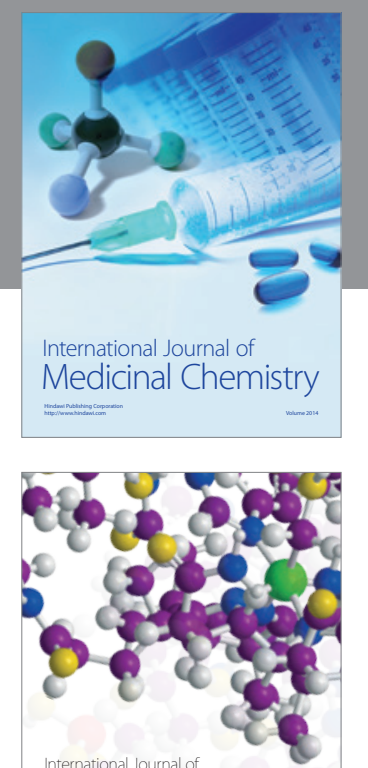

\section{Carbohydrate} Chemistry

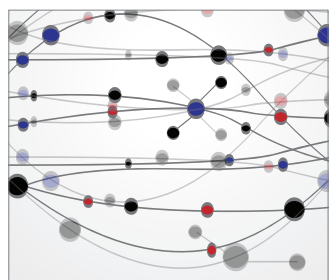

The Scientific World Journal
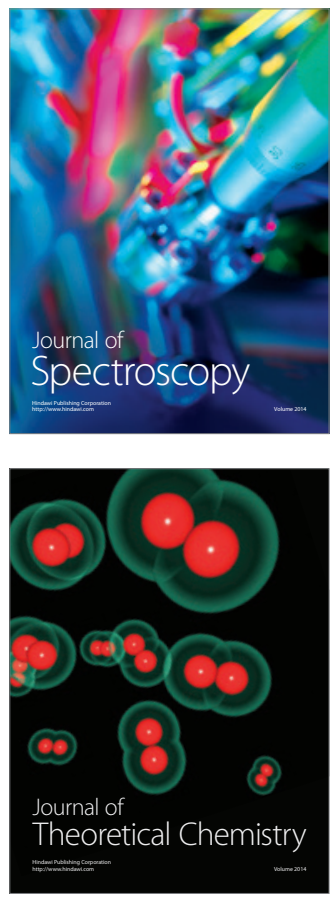
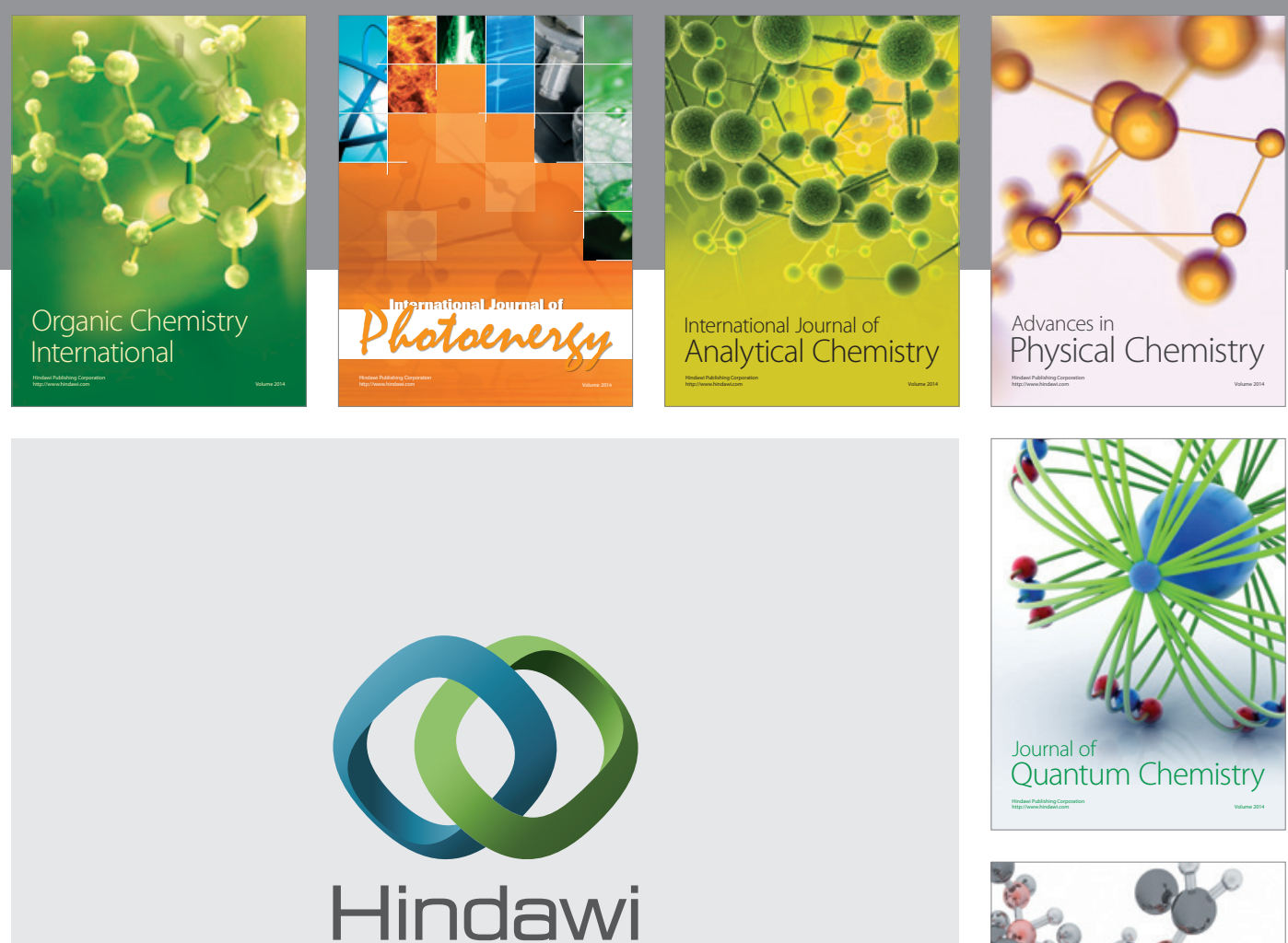

Submit your manuscripts at

http://www.hindawi.com

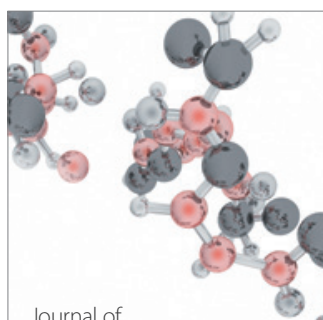

Analytical Methods

in Chemistry

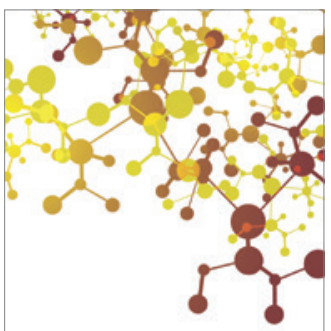

Journal of

Applied Chemistry

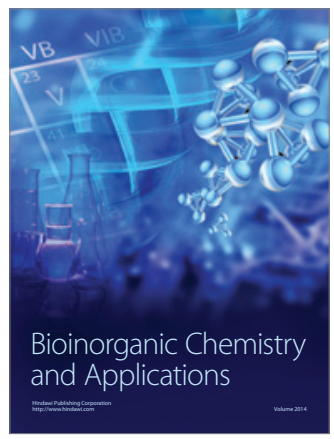

Inorganic Chemistry
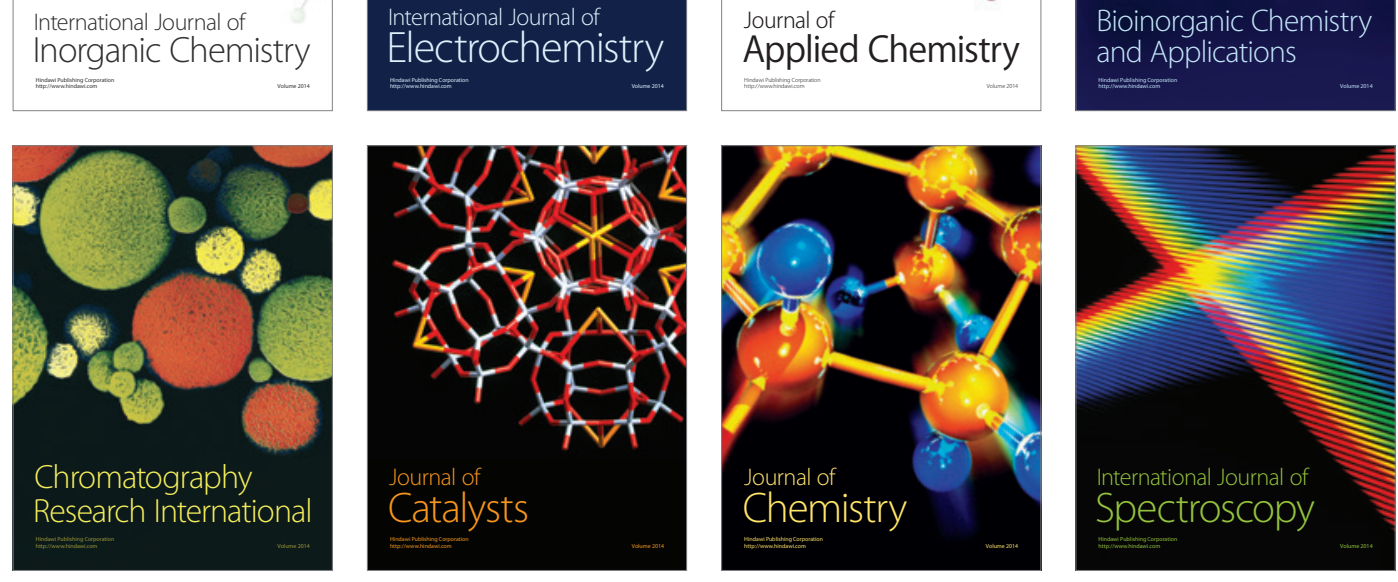